1. MBBS,

Resident of Medicine

Peoples Medical College Hospital

Nawabshah

2. MBBS, FCPS

Assistant Professor of Medicine Peoples University of Medical \& Health Sciences Nawabshah

3. MBBS, FCPS

Associate Professor of Medicine Peoples University of Medical \& Health Sciences Nawabshah

4. MBBS,

Resident of Medicine Peoples University of Medical \& Health Sciences Nawabshah

5. MBBS, MCPS, FCPS

Associate Professor of Medicine Peoples University of Medical \& Health Sciences Nawabshah

6. MBBS, MRCP (UK), Assistant Professor of Medicine Khairpur Medical College Khairpur Mirs

Correspondence Address:

Dr. Nasrullah Aamer

Associate Professor of Medicine

Peoples University of Medical \& Health

Sciences

Nawabshah

aamer.nasrullah@gmail.com

Article received on:

03/12/2019

Accepted for publication:

30/03/2020

\section{FREQUENCY OF ACUTE RENAL FAILURE IN BLACKSTONE POISONING}

\begin{abstract}
Ahmed Ali Kanhar ${ }^{1}$, Waseem Raja Memon ${ }^{2}$, Nasrullah Aamer ${ }^{3}$, Bahkat Ali Sial ${ }^{4}$, Abdul Aziz Sahito ${ }^{5}$, Safdar Ali Pervez ${ }^{6}$

ABSTRACT... Objective: To determine the frequency of acute renal failure in patients presented with Blackstone poisoning at tertiary care Hospital. Study Design: Cross sectional study. Setting: Medical wards and ICU at Peoples Medical College Hospital, Nawabshah. Period: September 2017 to March 2018. Material \& Methods: All the patients of age 20 to 50 years having Paraphenylenediamine (PPD) poisoning (kala-patthar) during $\geq 6$ hours after ingestion and either of gender were included. AKI was labelled as positive if either of any stage was present on the basses of urine output measurement for 24 hours through urine beg or urine output (UO) criteria. All the data was documented in self-made proforma. Results: The mean age for patients was $24.9 \pm 8.9$ years, $46(19.08 \%)$ subjects were male and $195(80.91 \%)$ were female. $18(7.5 \%)$ study subjects had acute renal failure, out of them 6 study subjects had ARF of stage I, 5 patients had stage II and 7 study subjects had acute renal failure stage III. Conclusion: Acute renal injury is a common complication following PPD ingestion Paraphenylenediamine toxicity is a threat to the region of Asia and is evolving as a substitute to the poisoning of organophosphorus due to its easy accessibility and low cost.
\end{abstract}

Key words: $\quad$ Acute renal failure, Blackstone poisoning, Urine output adults.

Article Citation: Kanhar AA, Memon WR, Aamer N, Sial BA, Sahito A, Pervez SA. Frequency of acute renal failure in blackstone poisoning. Professional Med J 2020; 27(6):1285-1290. DOI: 10.29309/TPMJ/2020.27.06.4392

\section{INTRODUCTION}

In Pakistan and other Asian countries, Black stone i-e; Paraphenylenediamine (PPD) is an agent used in hair dyes and Henna. This is also commonly called as Kala Pathar. It is most commonly used suicidal agent especially in Pakistan and India with the mortality rate ranging from $0.03-0.05 \%$ to $37.5 \% .^{1-6}$ However worldwide it has rarely been reported. ${ }^{6}$ PPD is associated with major life threatening complications like angioedema, laryngeal edema, respiratory failure, arrhythmias which occur initially in 4-6 hours, however the manifestations presenting late i-e; $>6$ hours- 12 hours are hyperkalemia $(87.5 \%)^{7}$, upper airway tract edema $(68.4 \%)^{8}$, metabolic acidosis $(84.6 \%)^{9}$, myocarditis, rhabdomyolysis $(37 \%)^{7}$, acute renal failure $(18 \%)^{7}$ and intravascular hemolysis. The clinical manifestations are directly correlated with amount of PPD, duration of ingestion and severity of complication. ${ }^{7-10}$ Elgamel et al found respiratory distress in $22.5 \%$, acute renal failure in $20.5 \%$, cardiac complications in
$1 \%$ and hepatic problems in $0.5 \%$ of patients. ${ }^{11}$ Severe angioneurotic edema develops in 4-6 hours followed by muscle pain in 12 hours and then rhabdomyolysis and muscle necrosis. Acute renal failure is the late manifestation developed after rhabdomyolysis and acute tubular necrosis. ${ }^{12}$ Khuhro et al has found $37.5 \%$ patients developing acute tubular necrosis and of them $12.4 \%$ patients developing acute renal failure after 72 hours. ${ }^{13}$ Acute renal failure usually occurs after moderate doses of PPD, however angioedema and hepatitis occurs on milder doses. ${ }^{13}$ PPD in hair dyes is available in the concentration of $0.2 \%$ to $3.75 \%$, and the lethal dose is $7-10$ grams, while only $3 \mathrm{gms}$ are associated with systemic toxicity. ${ }^{14}$ Another case report by Bokutz et al has found rhabdomyolysis together with laryngeal edema to be fatal complications of PPD. ${ }^{15}$ Prevalence of ARF is $6 \%$ in patients with Blackstone poisoning. ${ }^{16}$ Suicide is an avoidable public health concern, responsible for thousands of deaths globally per annum, and poisoning seems to 
be an ideal approach of committing suicide, which is among the major challenges faced in hospitals' emergency departments. Poisoning by PPD ingestion in numerous underdeveloped countries of Africa and Asia is a growing trend of deliberately harming oneself and is correlated with high mortality and morbidity. Thus, this study intended to identify acute kidney failure rate in patients presented with Blackstone poisoning.

\section{MATERIAL \& METHODS}

This was a cross-sectional study and conducted at ICU and Medical wards at Peoples Medical College Hospital, Nawabshah after approval of ethical committee. Study duration was six months from September 2017 to March 2018. All the patients of age 20 to 50 years, having Paraphenylenediamine (PPD) poisoning (kalapatthar) during $\geq 6$ hours after ingestion and either of gender were included. Patients on multiple drugs simultaneously with PPD kalapathar were conformed through history; patients with other associated medical conditions like hypertension (BP $>140 / 90 \mathrm{mmHg}$ ), asthma as per record or deranged LFT (ALT>40IU, AST>40IU), deranged RFT (creatinine $>1.2 \mathrm{mg} / \mathrm{dl}$ ) or anaemia $(\mathrm{Hb}<10 \mathrm{mg} / \mathrm{dl})$ and patients with previous cardiac problem or prolonged use of heparin or anticoagulants were excluded. Informed consent was taken from patients or their attendants. After being admitted to ICU or medical ward, patients were managed conservatively i.e., on arrival, each patient received parenteral steroids, antihistamines, sodium bicarbonate and gastric lavage, because, yet there is no specific antidote accessible for it. AKI was labeled as positive if either of any stage/s mention below were present on the basses of urine output measurement for 24 hours through urine beg or urine output criteria as: Stage 1: UO >0.5ml/kg/hr in 6 hours. Stage 2: UO > 0.5ml/kg/hr in 12 hours. Stage 3: UO $>0.3 \mathrm{ml} / \mathrm{kg} / \mathrm{hr}$ in 24 hours or anuria $\times 12$ hours. Performa was filled accordingly. SPSS.20 was used for statistical analysis.

\section{RESULTS}

Total 241 patients were enrolled, their mean age was $24.9 \pm 8.9(20-50)$ years, Mean duration of ingestion of poison was $8.9 \pm 10.9(6-72)$ hours, mean volume consumed was 75.2 \pm 38.4 $\mathrm{ml}$. 46(19.08\%) study subjects were male and $195(80.91 \%)$ were female patients. $148(61.41 \%)$ patients were illiterate and $93(38.58 \%)$ were literate, 103(42.73\%) patients were unmarried, 94(39\%) married, while 44(18.25\%) were divorced and widows or separated. Table-I.

Out of 18 study participants of ARF, 6(33.33\%) subjects had ARF of stage 1,5(27.8\%) patients had stage 2 and $7(38.9 \%)$ study subjects had ARF of stage 3 . Table-II.

Stratification for ARF was done with respect to age and gender. There was age $>30$ years and male gender were significantly associated with acute renal failure, $p$-values were quite significant, results showed in Table-III.

\section{DISCUSSION}

Para phenylene-diamine is a very potent poison employed for dyeing of hairs. It is very toxic to the human cells with lethal effects on different organs that results in rhabdomyolysis, myocarditis and angioneurotic edema. It is a growing method of self-poisoning because of its wide accessibility and low price. In our study, patients' mean age was $24.9 \pm 8.9$ years. $46(19.08 \%)$ study subjects were males and 195(80.91\%) were females. In comparison to our results, Naqvi $\mathrm{R}$ et $\mathrm{al}^{17}$ reported that mean age of their patients was $23.11 \pm 7.94$ years and acute kidney injury was caused by toxic rhabdomyolysis as suggested by a significant increase in muscle enzymes with mean creatinine. Shigidi $\mathrm{M}$ et $\mathrm{al}^{18}$ also reported a mean age of $25.6 \pm 4.2$ years with $93.3 \%$ females in majority and suicide due to PPD exposure was found in $86.7 \%$ cases.

The mean onset time for kidney symptoms was $34.8 \pm 7.6$ hours, the maximum median plasma creatinine was $8.6 \pm 2.3$ milligrams / dl, 86.7 percent had renal dysfunction as shown in the RIFLE distribution and dialysis was considered necessary. Rawat $\mathrm{R}$ et $\mathrm{al}^{19}$ reported females in majority with $21-30$ years of age group and $58.46 \%$ cases were presented with Nephro-toxicity. 


\begin{tabular}{|c|c|c|c|}
\hline \multicolumn{2}{|l|}{ Variables } & Frequencies(n) & Percentages \\
\hline \multirow{2}{*}{ Gender } & Male & 46 & $19.08 \%$ \\
\hline & Female & 195 & $80.91 \%$ \\
\hline \multirow{2}{*}{ Educational status } & Illiterate & 148 & $61.41 \%$ \\
\hline & Literate & 93 & $38.58 \%$ \\
\hline \multirow{3}{*}{ Marital status } & Unmarried & 103 & $42.73 \%$ \\
\hline & Married & 94 & $39.0 \%$ \\
\hline & Others & 44 & $18.25 \%$ \\
\hline \multirow{3}{*}{ Socioeconomic Class } & Lower & 105 & $43.56 \%$ \\
\hline & Middle & 84 & $34.85 \%$ \\
\hline & Upper & 52 & $21.57 \%$ \\
\hline \multicolumn{2}{|l|}{ Age $($ mean \pm SD) } & \multicolumn{2}{|c|}{$24.9 \pm 8.9$ years } \\
\hline \multicolumn{2}{|c|}{ Duration poisoning (mean \pm SD) } & \multicolumn{2}{|c|}{$8.9 \pm 10.2$ hours } \\
\hline \multicolumn{2}{|c|}{ Estimated volume consumed (mean \pm SD) } & \multicolumn{2}{|c|}{$75.2 \pm 38.4 \mathrm{ml}$} \\
\hline
\end{tabular}

Table-I. Distribution of demographic variables $(n=241)$

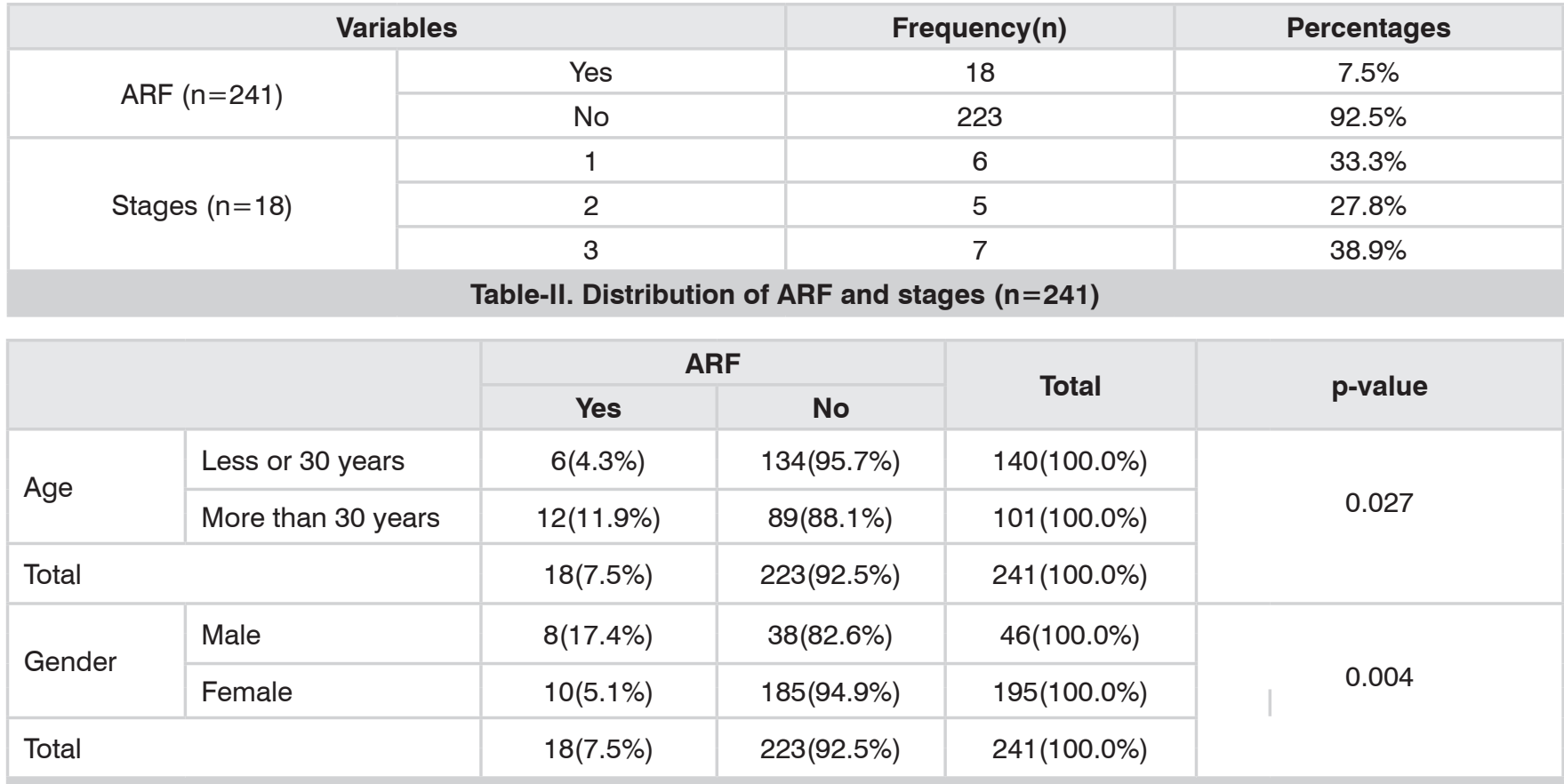

Table-III. Stratification for acute renal failure with respect to age and gender $(n=241)$

Khan MA et $\mathrm{al}^{20}$ showed that in their study; females were 814 (64.7\%) and males were 444 (35.3\%), with an age range of 5 - 63 years and 21 years of median age. In this study, most study subjects 148(61.41\%) were illiterate and the findings revealed a reciprocal association between the level of socioeconomic and educational status and Kala-Pathar poisoning, because Kala-Pathar intake was more common among the individuals with low socioeconomic status and lower education. Findings of other studies carried out in India and Pakistan, were consistent with ours. ${ }^{21}$ In present study, unmarried young females remained in majority, which is supported by prior reports published in Sudan. ${ }^{22,23}$ This may be because of unemployment, social insecurity, stress and overall less maturity in this age group. Females were affected more by intoxicating hair dyeing products. This can be explained by higher exposure of females to PPD contrasted to males, because hennais being used in skin cosmetics and in other cosmetics to enhance hair blackening. In 
this series, $42.73 \%$ subjects were unmarried while $39 \%$ were married patients. These findings are in line with nearly all the studies carried out in Asia and Africa. ${ }^{24}$ Furthermore, these outcomes are as well compliant with the self-harm report of WHO for low and middle income nations. ${ }^{25}$ The males to females ratio in adults is nearly similar to some local studies of Qasim et al. ${ }^{21}$ and Shakuntala et al. ${ }^{26}$ But, some studies from Africa and India revealed female victims much more than the findings of this study. Hair dye contains PPD at different ratios from 0.2 to 3.75 percent. PPD is a toxic substance that causes laryngeal edema, severe metabolic acidosis, rhabdomyolysis, and AKI following hair dye poisoning. ${ }^{27}$

In our study, $7.5 \%$ had ARF in which $33.33 \%$ study subjects had ARF of stage 1,27.8\% patients had stage 2 and $38.9 \%$ study subjects had ARF of stage 3 while Abdelrheem $\mathrm{MB}$ et $\mathrm{al}^{28}$ showed renal failure in $71 \%$. Another study conducted by Chugh et al. ${ }^{29}$ also documented two cases with acute oliguric kidney failure after intoxication by PPD. Paraphenylenediamine toxicity is a threat to the region of Asia and is evolving as a substitute to poisoning of organophosphorus due to its easy accessibility, bitterness and low cost. Hair dye toxicity in Pakistan seems to be a unusual causal factor of poisoning, initial appearance could be misleading and the majority of deaths can take place within hours of intake. Therefore, diagnosis needs a high suspicion index as clinical characteristics are unique. Early identification and therapy with particular focus on respiratory control and treatment/prevention of kidney failure is crucial for administrators. Given the growing prevalence of toxicity with this toxic substance, primary healthcare physicians, nephrologists and critical care physicians should be aware of this condition's different manifestations and administrative strategies.

\section{CONCLUSION}

Acute renal injury is a common complication following PPD ingestion. Clinical scenarios are based on prompt referral, early recognition, and aggressive treatment in support. Toxicity consciousness programs must be introduced at various levels. It is suggested that strong regulation and limitation of PPD sales besides consciousness. More such studies must be produced in peer-reviewed publications in order to persuade the officials and policymakers to give guidance.

Copyright $@ 30$ Mar, 2020.

\section{REFERENCES}

1. Gude D, Bansal DP, Ambegaonkar R, Prajapati J. Paraphenylenediamine: blackening more than just hair. J Res Med Sci. Jun 2012;17(6):584-6.

2. Sampathkumar K, Yesudas S. Hair dye poisoning and the developing world. J Emerg Trauma Shock 2009;2(2):129-31.

3. Jain PK, Agarwal N, Kumar P, Sengar NS, Agarwal $\mathrm{N}$, Akhtar A. Hair dye poisoning in Bundelkhand region (prospective analysis of hair dye poisoning cases presented in Department of Medicine, MLB Medical College Jhansi). J Assoc Physicians India. 2011:59:415-9.

4. Abdelraheem $M$, Hamdouk $M$, Zijlstra EE. Paraphenylenediamine (Hair Dye) poisoning in children. Arab J Nephrol Transplant. 2010;3:39-43.

5. Mahsud I. Role of tracheostomy in reducing mortality from kala pathar (paraphenylene diamine) poisoning. Gomal J Med Sci 2015;13(3):170-2.

6. Kondle R, Pathapati RM, Saginela SK, Malliboina S, Makineedi VP. Clinical Profile and Outcomes of Hair Dye Poisoning in a Teaching Hospital in Nellore. ISRN Emergency Medicine 2012:-2012,Article ID 624253, 5 pages.http://dx.doi.org/10.5402/2012/624253.

7. Sampathkumar K, Yesudas SS, Rajappannair PA, Mahaldar AR, Muthian R. Rhabdomyolysis due to hair dye poisoning: an emerging threat. Ind $\mathrm{J}$ Crit Care Med 2007;11:212-14.

8. Chaudhary SC, Sawlani KK, Singh K. Paraphenylenediamine poisoning. Niger J ClinPract. 2013;16(2):258-59.

9. Chrispal A, Begum A, Ramya, Zachariah A. Hair Dye Poisoning- an Emerging Problem in the Tropics: an Experience from a Tertiary Care Hospital in South India. Trop Doct 2010;40:100-3.

10. Akbar MA, Khaliq SA, Malik NA, Shahzad A, Tarin SM, Chaudhary GM. Kala pathar (paraphenylenediamin) intoxication; a study at Nishtar Hospital Multan. Anesth, Pain \& Intensive Care 2010;16(3);243-6. 
11. Elgamel A A, Ahmed $\mathrm{N}$ O. Complications and management of hair dye poisoning in Khartoum. Sudan Med Monit 2013;8:146-52.

12. Shafiq M, Maqbool F, Iqbal A, Baqai HZ. "Kala Pathar" Poisoning. J Rawal Med Coll 2015;19(1):98-9.

13. Khuhro BA, Khaskheli MS, Shaikh AA. Paraphenylene diamine poisoning: Our experience at PMC Hospital Nawabshah. Anaesth Pain Intensive Care 2012:16(3):243-246.

14. Ishaque S, Haq A, Jurair H, Siyal H. KaalaPathar (Paraphenylene Diamine) Poisoning and Angioedema in a Child: an Unusual Encounter. $J$ ClinToxicol2016;6:294.

15. BokutzM, Nasir N, Mahmood F, Sajid S. Hair dye poisoning and rhabdomyolysis. J Pak Med Assoc 2015;65:425-6.

16. Kondle R, Pathapati RM, Saginela SK, Malliboina S, Makineedi VP. Clinical profile and outcomes of hair dye poisoning in a teaching hospital in Nellore. ISRN Emergency Med. 2012 Mar 1;2012.

17. Naqvi R, Akhtar F, Farooq U, Ashraf S, Rizvi SA. From diamonds to black stone; myth to reality: Acute kidney injury with paraphenylene diamine poisoning. Nephrology. 2015 Dec;20(12):887-91.

18. Shigidi M, Mohammed O, Ibrahim M, Taha E. Clinical presentation, treatment and outcome of paraphenylene-diamine induced acute kidney injury following hair dye poisoning: a cohort study. The Pan African medical journal. 2014;19.

19. Rawat R, Kumar M, Singh PS, Kumar G, Verma V. Study of hair dye poisoning and its outcome in tertiary care rural institute. International Journal of Research in Medical Sciences. 2016 Aug;4(8):3240.

20. Khan MA, Akram S, Shah HB, Hamdani SA, Khan M. Epidemic of kala pathar (paraphenylene diamine) poisoning: an emerging threat in southern Punjab. $\mathrm{J}$ Coll Physicians Surg Pak. 2018 Jan 1;28(1):44-7.
21. Qasim PA, Ali MA, Baig A, Moazzam MS. Emerging trend of self-harm by Kala Patharhair dye (paraphenylene diamine): An epidemiological study. APMC2016; 10:26-30.

22. Jain PK, Agarwal N, Sharma Ak, Akhtar A. Prospective study of ingestional hair dye poisoning in Northern India (Prohina) J Clin Med Res. 2011;3:9-19.

23. Suliman SM, Fadlalla M, Nasr ME, Beliela MH, Fesseha $\mathrm{S}$, Babiker M, Musa ARM. Poisoning with hair dye containing Paraphenylene-diamine: Ten years experience. SJKD. 1995;6(3):286-289.

24. Suliman SM, Homeida M, Aboval OI. Paraphenylene diamine induced acute tubular necrosis following hair dye ingestion. Human Toxicol2008; 2:633-5.

25. WHO - World Health Organization. http://www. who.int/ gho/mental_health/en

26. Shakuntala P, Khan M, Sudarsi B, Manohar S, Siddeswari $\mathrm{R}$, Swaroop K. Clinical profile and complications of hair dye poisoning. Int J Sci Res2015;5:1-5.

27. Sampathkumar K, Sooraj Yesudas S. Hair dye poisoning and the developing world. J Emerg Trauma Shock. 2009;2(2):129-131.

28. Abdelraheem MB, El-Tigani MA, Hassan EG, Ali MA, Mohamed IA, Nazik AE. Acute renal failure owing to paraphenylene diamine hair dye poisoning in Sudanese children. Ann J Trop Paediatr. 2009;29:1916.

29. Chugh, KS, Malik, OH, Singhal, PC. Acute renal failure following paraphenylene diamine (hair dye) poisoning: report of two cases. J Med 1982; 13: 131137. 


\begin{tabular}{|c|c|c|c|}
\hline \multicolumn{4}{|c|}{ AUTHORSHIP AND CONTRIBUTION DECLARATION } \\
\hline Sr. \# & Author(s) Full Name & Contribution to the paper & Author(s) Signature \\
\hline 2 & $\begin{array}{l}\text { Ahmed Ali Kanhar } \\
\text { Waseem Raja Memon }\end{array}$ & $\begin{array}{l}\text { Data collection, and } \\
\text { manuscript writing. } \\
\text { Manuscript review. }\end{array}$ & $\sum_{\text {sint }}$ \\
\hline 3 & Nasrullah Aamer & $\begin{array}{l}\text { Data analysis and manuscript } \\
\text { writing. }\end{array}$ & \\
\hline 4 & Bahkat Ali Sial & Participation in data collection. & C.syl. \\
\hline 5 & Abdul Aziz Sahito & Participation writing and review. & \\
\hline 6 & Safdar Ali Pervez & Participation in data analysis. & 1) $+4 g^{\prime}$ \\
\hline
\end{tabular}

